Meta

Journal des traducteurs

Translators' Journal

\title{
Critique of Aspects of Translation of the Poetry of Pre-Islamic Poets and also of "Wormhoudt's" Translation of al-Mutanabbi
}

\section{Salah Salim Ali}

Volume 35, numéro 4, décembre 1990

URI : https://id.erudit.org/iderudit/001872ar

DOI : https://doi.org/10.7202/001872ar

Aller au sommaire du numéro

\section{Éditeur(s)}

Les Presses de l'Université de Montréal

\section{ISSN}

0026-0452 (imprimé)

1492-1421 (numérique)

Découvrir la revue

Citer cet article

Salim Ali, S. (1990). Critique of Aspects of Translation of the Poetry of Pre-Islamic Poets and also of "Wormhoudt's" Translation of al-Mutanabbi. Meta, 35(4), 732-741. https://doi.org/10.7202/001872ar
Résumé de l'article

Errors arise in the translation of poetic literature as a result of gaps in the translator's knowledge of the historical, social, and cultural context in which the poem was written. However, it is not enough for the translator to have knowledge of this sort, he must also know about the kind of idiomatic expressions in vogue which the poet tends to use and the contemporary allusions intended in his choice of words, metaphors..., etc. A further source of error stems from a misunderstanding of grammatical, or stylistic features of the poetry. All poets manipulate the grammar of their language in their own characteristic way. Unless the translator is well acquainted with these features, he may not faithfully represent their semantic effect in the target language. This paper deals with some cultural and linguistic aspects of some translations of the pre-Islamic poets and also of "Wormhoudt's" translation of al-"Mutanabbi" with examples of errors arising from cultural and linguistic misunderstanding. 


\section{CRITIQUE OF ASPECTS OF TRANSLATION OF THE POETRY OF THE PRE-ISLAMIC POETS AND ALSO OF "WORMHOUDT'S" TRANSLATION OF AL-MUTANABBI}

SALAH SALim Ali

Turkish Studies Centre, The University of Mosul, Mosul, Iraq

\section{ABSTRACT}

Errors arise in the translation of poetic literature as a result of gaps in the translator's knowledge of the historical, social, and cultural context in which the poem was written. However, it is not enough for the translator to have knowledge of this sort, he must also know about the kind of idiomatic expressions in vogue which the poet tends to use and the contemporary allusions intended in his choice of words, metaphors..., etc.

A further source of error stems from a misunderstanding of grammatical, or stylistic features of the poetry. All poets manipulate the grammar of their language in their own characteristic way. Unless the translator is well acquainted with these features, he may not faithfully represent their semantic effect in the target language.

This paper deals with some cultural and linguistic aspects of some translations of the pre-Islamic poets and also of "Wormhoudt's" translation of al-"Mutanabbi" with examples of errors arising from cultural and linguistic misunderstanding.

\section{BACKGROUND TO CLASSICAL ARABIC POETRY}

Most studies of Arabian life in the pre-Islamic period concentrated on the explanation of poetry, regardless of cultural and linguistic background, or else on the description of culture and social life, irrespective of language and poetic heritage. It must be pointed out that both poetry, as the main cultural asset of the pre-Islamic Arabs, and Bedouin life are interrelated. They are almost one and the same phenomenon. This degree of interdependence between poetry and daily life is not always paralleled in other cultures such as the English culture.

A further point of difference between Arabic and English is that linguistic studies in Arabic were first founded on poetic studies and the earlier works on grammar and linguistic analysis were primarily based on patterns borrowed from classical poetry as the only reliable reference to resort to on controversial points of syntactic and lexical accuracy, ${ }^{1}$ while in English, poetry is not generally regarded as the model for grammatical accuracy and is more likely to be held by linguists as an example of deviant grammatical structure. ${ }^{1}$

It is worth pointing out too that the early Arabic poems were not written but committed to memory and transmitted by oral traditions, and scholars started recording them only in a later period during the 2 nd and 3 rd centuries of the Hijrah.

The climatic and environmental features of the Arabian peninsula seem to have conditioned many patterns of behaviour, including social relationships, moral values, and even the type of imagery al-majäz highlighted in poetic metaphors. Arabia is one of the driest and hottest deserts, with a predominantly rainless climate and a scarcity of resources, in addition to the dry wind as-sumūm that slashes the desert and leaves its effects 
in seasons of drought that might well last for 3 or 4 years, giving rise to famine, infanticide and wars among tribes. Nevertheless, there were periods and places where conditions were less severe, for beside the bitter colocynth there also existed the sweet dates. From the latter, the Bedouin used to make his wine nabidh and from their stones he used to feed his camel, his only companion in that harsh environment. The camel was the alter-ego of the Bedouin, his ship of the desert and the gift of God. Arabic boasts of some thousand names for this creature with all its different breeds and activities.

But in contrast to this barren environment of Arabia, which suffered from a lack of variety in flora and fauna, the Arabic language abounds in colourful expressions. Instead of devoting its resources to describing a wide variety of distinct referents, Arabic tended to multiply a particular concept into numerous shades of meaning. E.g. for the impact things leave on the hand after being touched, Arabic uses some fifty words to describe the different effects: thus after touching meat the hand becomes ghamira; chicken, zamira; eggs, zafira/madhira/zahika; butter, wadira; fish, sarima; oil, qanima, cooked beef, zanikha, etc. ${ }^{3}$ This wide range of vocabulary provides the poet with rhymes and rhythms both to satisfy the rigid conventions of poetry and to please his listeners.

It is worth bearing in mind that the very form of Arabic poetry is a reflection of the Bedouin nomadic life. The monorhyme is the verbal counterpart of the camel's simultaneous and symmetrical leg movement. The very structure of the Arabic poem al-Qasida is defined according to the different parts of the goat-hair tent, e.g. each line is called bayt "home" which is a synonym for "tent" and consists of two hemistichs misrä meaning "half of the folding door of the tent." The first hemistich is called as-sadar, "the breast or the front of the tent," and the second, alcajuz, "the rump or the rear part of the tent." The ropes bind the tent fast to the ground and the same binding effect is given to the poem by the last letter of the rhyme designated as harfu r-rawi, "the binder," which remains the same all through the poem and holds the lines together. The last foot of the first hemistich is called al-carind, "the chief support of the tent." The conventions of Bedouin poetry have continued up to modern times for we still find poems of praise, madih, and of invective, hija, and love, nasi $b$, which started as a compulsory conventional prelude to every poem and then developed as an autonomous form on its own.

\section{THE NATURE OF THE POETIC LANGUAGE OF CLASSICAL ARABIC}

Arabic is a highly metaphorical language. The tendency of the Bedouin Arabs towards metaphor was all too evident in Arabic which abounds in idiomatic and metaphorical expressions that substitute a highly colourful and kaleidoscopic panorama for the bare colourless life of the desert. But to understand the implications of some of the poetic metaphors and idioms we have to refer to the historical and cultural origin. We still find aspects of earlier patterns of life in the forms of idioms and metaphors in pre-Islamic poetry which, when not properly understood, may lead to serious mistakes in translation. Instead of saying "in the sky" a Bedouin used to say "in the liver of the sky" fi kabidi's Sam $\vec{a}$ " or "on the forehead of the sky" calā jabinin' s-Samä'. Other examples are: "the situation reveals that": "the tongue of the situation says", lisānn l-hāli yaqül; "in the middle of the night": "in the jaws of the night, fi jawfi l-layl; "the matter reached a climax": "the flood is brimming over", balagha s-Saylu $z$-Zubā" "shall we discuss the question or suspend it": "shall we lay the question on the carpet of discussion or shall we fold the carpet with whatever it contains", hal natrah l-mas'ala calä bisäti l-bahthi am natwì l-bisäta bimä fihi; etc.

There is also a tendency to use metonymical expressions al-kinäya, which are characteristic of the classical Arabic style, such as tawilu' n-nijād, literally, - having a long belt - "tall." Nijäd here refers to the belt with which the sword is held by its hilt to 
the body. Another example is kathiru ramād, literally — having a lot of ashes - "generous"; here the expression kathiru ramäd " $l$-qidri, "his is a container with a lot of ashes," has been clipped. It actually means he has lots of ashes in his kitchen to signify the remains of burned wood and charcoal used for continuous cooking for his guests, that is to say he is always having guests and cooking food for them.

These examples indicate that the definition Leech quotes for metonymy from Webster's Third New International Dictionary - "A figure of speech that consists in using the name of one thing for that of something else with which it is associated" - is applicable to the use of metonymy in Arabic though it is sometimes defined so broadly as to include metaphor and synecdoche as well.

Metonymy and metaphor, however, are only two obvious properties of poetic language and the translator can usually manage to find an equivalent meaning for them. Nevertheless ambiguity may well arise from the lack of an equivalent concept in English or from polysemic words that do not have the same semantic range in English. In the first category we find such words as al-jadìdān, "the two news ones" meaning day and night, and al-aswadān, "the two black things" meaning the bread and date. In the second category we find such words as hawd meaning water-tank, family, battlefield, container, pelvis, as well as domain or area to be protected; fuhül meaning distinguished personalities, luminaries, stars, masters, and stallions; thīyāb meaning the heart, the body, the garments, and many other words.

In Arabic classical poetry we notice that every line deals with an independent image which can be considered as a single semantic unit. Thus a classical poem resembles a train of successive pictures each one representing a façade of a given landscape and each line has a distinctive tone corresponding to the poet's feelings. These poems are called $m u^{c}$ alladāt because the Bedouins took them for icons and had them hung on the wall of their sacred temple $a l-k a^{c} b a$ giving them a sacred status. This illustrates a relation between decorative art, i.e. calligraphy and interior design, and poetry in the imagination of the pre-Islamic Arabs. It also accounts for the description of poetry as: $\operatorname{tarsi} \bar{i}^{c}$, a term used in jewellery making, and $t a d b i j$ which is again used in decorative art, while the word used for all the figures of speech is mudabbajāt, "the decorated or embroidered works." Thus a poem is like a necklace made of colourful beads, the best line being wāsitatu "lciqd, "the paragon" or "the biggest jewel" of these beads.

This may shed some light on the workings of the Bedouin imagination. So in the Imru' ul-Qais mucallaqa the interlude conventionally starts with nasi $i$, "love poetry," then it moves on to the description of feminine beauty with some minute shifts in scenery, then follows with a series of images describing natural phenomena such as the night, the desert, and the horse. Each line represents a single picture that is related by a central image e.g. horse, night, rain to other pictures. The poem then ends with several similes describing the rain, the flood, and the scum that the torrential rain brought down along with drowned beasts.

It is well worth pointing out that almost every line of pre-Islamic poetry contains a simile, a metaphor or several figures of speech interlaced with each other, so that a metaphor can be extended into a simile as in the line by Imru' ul-Qais:

Tudī' u z-zalāma bi-lcishā'i ka-annahā manāratu mumsā rāhibin mutabatilī

Az-zawzani (1948): p. 26.

At eventide she lightens the black shadows, as if she were the lamp kindled in the night of a monk at his devotions.

Arberry (1957): p. 63 . 


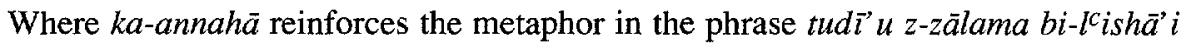
with a simile expressed by the "rump" - the second half of the line - manäratu mumsā răhibin mutabatilī. Alternatively a personification may circumscribe a simile as in the following line by Imru' ul-Qais:

Wa-laylin ka-mawji'lbahri murkhin sudūlahu calayya bi-anwãci l-humümi li-yabtali.

Az-zawzani (1948): p. 29.

Oft night like a sea swarming has dropped its curtains over me, thick with multifarious cares, to try me.

Arberry (1957): p. 64.

where the simile contained in the phrase: ka-mawïlbahri murkhin sudūlahu, etc. is circumscribed by the personification denoted by the words wa-laylin and li-yabtali. We also notice in the pre-Islamic poems $a l$ - $m u^{c}$ allaqät that more than one word can carry the metaphorical meaning. If we consider the following sentence:

"He ploughed through the discussion."

We find that the word "ploughed" is the focus of the metaphor while other words constitute a frame to this focus, and that both the focus and the frame are integral parts of the metaphor. This is an example of a simple metaphor that tends to have one prominent focus, while in some lines of al-mucallaqāt we find that the metaphoric meaning is expressed by more than one word which are all equally powerful in expressing the metaphor. Most metaphors employed in pre-Islamic poetry are of a complex nature, for we can hardly distinguish the frame from the focus in them, as in the following line by Imru' ulQais:

faqultu lahu lammā tamatā bi-sulbihi wa-ardafa acjāzan wa-nā'a bi-kalkalī.

Az-zawzani (1948): p. 29.

And as I said to the night, when it stretched its lazy loins followed by its fat buttocks, and heaved off its heavy breast.

Arberry (1957): p. 64.

Here, we notice that all the underlined words contribute equally to the metaphoric strength. These metaphors, though complex, are self-explanatory and cause little difficulty for the translator. Translation errors are caused, however, by ambiguous expressions resulting from ellipsis as in Wormhoudt's translation of al-Mutanabbī or from failure to capture the contextual meaning of a polysemic word or of ambiguous expressions such as: wadacahu calä r-raffi which means both "to put something aside" as being done with and no longer necessary, and literally: "to put something on the shelf"; irtafac a sawtahu which means both "he gained prestige" and literally: "his voice grew louder"; similarly with taqalasa zillahu which means both "his prestige has vanished" and literally: "his shadow has dwindled," etc.

Other figures of speech which may cause difficulty to translators are proverbs and idioms that are either borrowed from common maxims and sacred literature or that occur in poetry and later turn into proverbs in their own right. English can often provide equivalent idioms for Arabic culture-bound expressions, with some differences in the terms used to express a similar meaning in both languages. Thus, "he has no hand in the troubles" for laysa lahu isbican fi-l-mas'ala, literally: "he does not have a finger in the matter," and "pull up your socks" for shammir can sācidayka'ljid, literally: "roll up your sleeves." Wide reading experience with an adequate bilingual dictionary will save the 
translator much difficulty in translating idioms such as the above, but the problems which dictionaries cannot solve are those arising from certain expressions describing a particular obsolete pattern of behaviour. Translators may fail to capture certain cultural implications contained in certain words or even in a whole line, thus leading us to another area of problems arising from culture-induced errors.

\section{CULTURE-INDUCED ERRORS}

In the mucallaqa of the pre-Islamic poet Imru' ul-Qais, Arberry translates the line:

Wamā dharaft ${ }^{c}$ aynāki illā li-tadrib̄i bi-sahmayki fĩ a ${ }^{c}$ shāri qalbin muqattalī.

Az-zawzanī (1948): p. 15.

as

Your eyes only shed these tears so as to strike and pierce with those two shafts of theirs the fragments of a ruined heart.

Arberry (1957): p. 62

The phrase "fragments of a ruined heart" fails to capture the cultural reference implied by the word $a^{c} s h \bar{a} r$. This word refers to the pre-Islamic practice of gambling, $a l$ maysir ${ }^{5}$, by aiming arrows at a given target. If the arrow hits a particular goal, the gambler will either lose or win one of two shares, or both of them. The greater part consists of seven units which is called alqidhu'lmucallä which was the origin of the idiom lahu' lqidhu'lmucallā, "he has the greater share," with the smaller part alraqib consisting of three units. Imru' ul-Qais by the word $a^{c} s h a \bar{r}$, "tenths", refers to both parts: al-qidh al$m u^{c}$ alla and alraqïb which means the "whole of my heart" and not "fragments" as Arberry translates it. A more faithful translation would be:

Your eyes only shed those tears so as to smite with those two shafts of theirs the whole of a ruined heart.

Nicholson states in his commentary on the translation of al-mucallaqăt:

It must be confessed that no rendering of the mucallaqat can furnish European readers with a just idea of the originals, a literal version least of all. They contain much that only a full commentary can make intelligible much that to modern taste is absolutely incongruous with the poetic style.

Nicholson (1930): p. 103.

The moralist poet "Zahair" compares war to a destructive fire, then to a grindstone crushing people like grains. He intensifies the horrific image of war by quoting a proverb which is very rare if not completely extinct in modern Arabic. In his description of war between the two tribes ${ }^{c} A b s$ and Dhubyān he uses the proverb ${ }^{c} i t r a$ Minshami:

Tadāraktumā c Absan wa Dhubyāna bac damā tafānaw wa-daqqū baynahum citra Minshamì. Az-zawzani (1948): p. 98.

You alone mended the rift between Abe and Dhubyan after long slaughter, and much grinding of the perfume of Manshim.

Arberry (1957): p. 151

Once again Arberry fails to convey the meaning of this idiom for a literal translation of the word daqqu as "grinding" would fail to transmit the cultural implication of the verse. The fact is that this perfume is the sign of a bad omen. It goes back to the story of two tribes who bought a herb perfume from a druggist woman called Minsham and 
contracted to join forces in an offensive. They all put their hands in that perfume as a sign of agreement, but where all savagely exterminated. There is no way of conveying this allusion other than by a commentary, though an alternative translation with a minor modification to Arberry's version may bring out the bad connotation implied by the "perfume of Minsham." Thus:

You alone mended the rift between ${ }^{c}$ Abs and Dhubyān after long slaughter and much grinding and dividing of the ill-omened perfume of Minsham.

Difficulty of interpretation sometimes arises in the case of polysemous words in which one or more of the meanings have become obsolete in the modern language. The word thi $\bar{y} \bar{a} b$ is an example of this. It had three meanings: "garments,", "feelings/heart," and "body." The metonymical expression tahiru "l-thìyäb, literally meaning - pure of garments - means "honest," "having good manners or good moral make up." Similarly with the idiomatic expression fidan laka thawbayya, "I sacrifice for you both my heart and body," where thawbäya, "my two garments", is used instead of "my heart and body." In the following translation by Arberry, Imru' ul-Qais used the word thiy $b$ in its former metaphoric sense i.e. "heart":

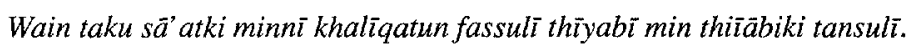

Az-zawzani (1948): p. 15.

If it's some habit of mine that's so much vexed you just draw off my garments from yours, and they will slip away.

Arberry (1957): p. 62.

It is evident that Arberry had adopted the modern sense of the word thīyäb in Modern Standard Arabic which does not refer to moral character, feelings, or body and might even escape the notice of modern readers. Imru' ul-Qais rather means disengage my heart from yours and not my "garments" as translated by Arberry. Nicholson's translation contains the same mistake:

Nay, if thou so mistakest aught in me shake loose my robe and let it fall down free.

Nicholson (1930): p. 106.

A modification in the light of the aforementioned discussion will keep Arberry's translation with a minor change thus:

If it's some habit of mine that's so much vexed you just disengage my heart from yours, and let it be free.

Failure to capture the cultural reference in a given line as well as the metaphoric extension of certain words can lead to translation errors in the same passage. This may be illustrated from Arberry's translation of these two lines by "Zuhair ibn-Abī-Sulmā ( 530 627 A.D.):

Waman ya ${ }^{c}$ si aträfa r-rimähi fa' innahu yutīc u lcawāli rukkibat kula lahdhami,

Waman lam yadhud can hawdihi bisilāhihi yuhaddam waman là yazlumi n-nāsa yazlami, Az-zawzanī (1948): p. 111

Whoever refuses to yield to the ends of spears iron heels shall surely bow to the sharp tips mounted on their upper shafts, whoever defends not his water-tank with his goodly-weapons will see it broken, whoever assaults not others is himself assaulted.

Arberry (1957): p. 117. 
The first line refers to a war custom of the early Arab tribes. Either one of the contending parties would turn the heels of their spears before initiating war as a sign of their wish for peaceful negotiation; if the other party did the same, representatives of both tribes would take on the role of concluding peace. The poet refers to this custom in the first line. In Arberry's translation the word "yield" has the sense of "surrender" or "capitulation." When read by modern readers, the English version would certainly miss the cultural implication of this line for it gives no explanation why one should yield to the ends of the spears' iron heels. In the second line the word "water-tank" does not convey the sense of the Arabic word hawdihi ${ }^{6}$ which in this context means his home and sacred possessions, including land and family, and not "water-tank" as Arberry translates it literally. A commentary would be necessary to fully elucidate the cultural implications of the first line. However, a better translation of this verse would be:

Whoever refuses to resort to peace at the sight of turning the spears iron heels shall surely bow to the sharp tips mounted on their upper shafts. Whoever defends not his home with his goodly weapons will see it broken, whoever assaults no others is himself assaulted.

A further category of translation errors arises as a result of the translator's failure to understand Arabic grammar. We will term these "linguistically-induced errors."

\section{LINGUISTICALLY-INDUCED ERRORS}

In Wormhoudt's translation of al-Mutanabbī, mistakes arising from gaps in the translator's knowledge of Arabic grammar occur. Such mistakes are sometimes accompanied by culture-induced errors as well. A translation of a given line can be accurate, but it remains for the translator to make clear the particular cultural connotations associated with certain words in the poem, either by expanding them or commenting on them.

The following line:

Ka'anna laswada läbīya finhim ghuräbun hawlahu rakhmun wa, bümu,

was translated by Wormhoudt:

As if the Nubian blacks were crows, around them vultures and owls.

Wormhoudt (1978): p. 503.

Wormhoudt pluralized the singular word al-aswada, "the black", into "blacks" and made the pronoun him expressed in the same line by fí him' coreferential with the qualified noun al-aswada. This distorts the meaning since the central object of satire hija ${ }^{\prime}$ here is "Kăfür" the black ruler of Egypt who was compared to a crow surrounded by vultures and owls. The prepositional phrase: fihim, "amidst them", belongs to the word "slaves" in the previous line:

Hasaltu bi' ardi Misra calā 'abìdin (slaves) ka' anna lhurra baynahumū yatīmu.

Furthermore, the connotation of the "owl" in the Arab world is that of a bird of bad omen whereas it does not necessarily have this association in the West. An alternative translation that avoids linguistic errors and conveys the connotative value is:

As if the Nubian black amongst them were a crow surrounded by vultures and ill-omened owls.

Knowledge of Arabic morphology or "accidence" $c_{i l m u}$ s-sarf is very necessary for translators whose mother tongue is not Arabic because the derived forms from the base form of the triliteral and quadriliteral verbs in Arabic express various modifications of the idea conveyed by the root. They determine whether the verb has a transitive or 
intransitive meaning as well as distinguishing between a temporary state or condition, or merely accidental qualities in persons or things. ${ }^{7}$ They can, therefore, affect syntactic relationships and consequently have a bearing on the interpretation of verse. In the following translation by Wormhoudt of al-Mutanabbī an example of misunderstanding Arabic morphology that led to a serious syntactic error is provided:

Mazilu udhiku iblïkullamā nazarat ilā mani khtadabat akhfäfuhā bidami Usayyiruhā bayna asnāmin ushāhiduhā walä ushāhidu fih ä ciffat s-sanamī.

\section{Wormhoudt's translation is:}

I can't stop smiling at my camel as she looks at what colours her hoofs with blood, I led her among idols to show them to her but I found among them no idol's chastity.

Wormhoudt (1978): p. 497.

Misunderstanding the morphology of the verb udhiku, "making somebody - and in this context - making the camels - laugh" on the one hand, and substituting the singular form "camel" for the plural "camels" as implied in the Arabic word ibli, on the other hand, led to the translation error in relating the act of "laughing" to the poet rather than to the camels. It is not the poet who smiles at his camels, but rather the camels that are made to smile at other camels referred to here by the word akhfäfuha, "pads", which the translator mistook for "hoofs": sanäbik. The camels here are personified and made to laugh by the poet as he leads them among other camels whose pads are stained - as the context implies - with the blood of his enemies. There is a similar problem in the second line, concerning the meaning of the phrase usayyiruhā bayna asnāmin ushähiduha $\bar{a}$. The verb ushähiduha refers to the act of seeing on the part of the poet i.e. the poet sees these idols and not the "camels" as Wormhoudt's translation suggests in the phrase: "to show them to her." These idols refer to the poet's enemies and critics that he sees while leading his camels through their dwellings. He makes a comparison between the stone idols which he maintains as chaste and those human idols among his enemies who are - according to his mind's eye - not chaste. An alternative translation is:

I still make my camels laugh at their like with blood stained pads, I lead them among idols I see but I see not in them the chastity of idols.

Further errors arising from misunderstanding Arabic morphology occur in Wormhoudt's translation of the following line by al-Mutanabbī:

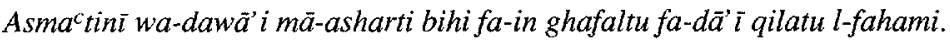

It made me hear, my cure was its advice if I slip, my ransom is I have little wit.

Wormhoudt (1978): p. 497

Again, mistaking the morphology of the word asmactini, "you made me hear you", which comes as a direct reply on the part of the poet to the "pens" statement: (never write with us but after "writing" with the sword for indeed we are like servants to the swords). In this line the pens are personified and are talking to the poet and the poet answers accordingly. Wormhoudt incorrectly vocalized the word asmactini, "you made me hear" as asmacatni, "it made me hear." Thus changing the focus implied by the dialogue from a direct conversation between the poet and the pens - personified - to a statement between the poet and a third person. It follows that the pronoun in the phrase $m \bar{a}$-asharti bihi, "your advice", is also changed to the third person pronoun referred to in the English version by the phrase: "its advice." In the second half of the same line we 
notice that the translator mistakenly analyses the third word $f a-d \bar{a} \cdot \vec{l}$, which consists of $f \bar{a}^{\prime} u$-ljaw $\bar{a} b$ : (the particle introducing a clause that expresses the result or effect of a

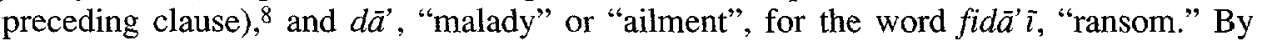
doing this he drastically changes the meaning of the verse. An alternative translation of the line is:

You made me hear and your advice my remedy, if I mistake $\mathrm{O}$ me: forgetful mind my malady.

Ellipsis is another feature of Arabic poetry which may lead translators to make serious mistakes. Wormhoudt's translation of the following line by al-Mutanabbi is an example:

Wa- ${ }^{c}$ ayni ilā udhunay aghara ka'annahu mina-layli bāqin bayna caynayhi kawkabu

My eye was on elegant ears as if they were a bit of night "twixt its eyes a star.

Wormhoudt (1978): p. 467.

The translator failed to capture the ellipted noun implied by the adjective aghara. It is a characteristic of Arabic to use the adjective of a noun in certain collocations to refer to the ellipted noun. Arberry, in his translation of a line by Imru' ul-Qais:

Wamā dharafat caynāki... etc.

introduced the ellipted object, which does not exist in the Arabic version. Thus he introduced the word "tears":

Your eyes only shed (those tears)... etc.

But here Wormhoudt, in missing the ellipted noun, makes a serious mistake. For it is "the horse" which is elegant and not the ears. The phrase "ayni ila referring to the act of seeing, it literally means: "my eyes were fixed at." Another syntactic misinterpretation in the translation concerns the preposition min which is not used in this context in its "made of" sense but rather in its "of" sense: "a star of the stars of the night." An alternative translation would be:

While my eyes were fixed on the ears of my elegant horse as if a star were left betwixt his eyes by the departed night.

\section{CONCLUSION}

From the aformentioned account it is clear that:

(a) Classical Arabic poetry is deeply rooted in pre-Islamic culture and its translation necessitates full reference to the cultural and social environment of the poet in order to bring out the correct meaning of idioms, proverbs, and the cultural connotations of words and expressions in poetry.

(b) While culture-bound idioms are the main reason for error in Arberry's translation of the $\mathrm{mu}^{\mathrm{c}}$ allaqāt, incomplete knowledge of the mechanisms of Arabic language, as well as of Arabic culture, lies behind certain errors in Wormhoudt's translation of alMutanabbĩ.

\footnotetext{
Notes

1. Sharh Ibn caqil is an example of these studies and is still taught as a University Grammar of Arabic.

2. Leech (1980): pp. 44-45.

3. Nāsiru'd-Din (1968): p. 48.
} 
4. Black (1962): p. 26-30.

5. Al-Bāqillänī (1977): p. 79.

6. See p. 5 for the various meanings of the word hawd.

7. Wright (1977): pp. 29-30.

8. Cachia (1973): p. 73

9. The poet was watching the movement of his horse's ears for fear of approaching enemies.

\section{REFERENCES}

AL-BĀQILLĀNĪ, A. M. (1977): $I^{c} j a ̄ z u-l-Q u r^{\prime} a ̄ n$, Caire, Dāru'l-macārif. ARBERRY, A. J. (1957): The Seven Odes, Cambridge, C.U.P.

AZ-ZAWZANI, A. A. I. (1948): Sharhu-lmucallaqāti-'lsab'a, Caire, Muhammad Ali Sabih.

BLACK, M. (1962): Models \& Metaphors: Studies in Language and Philosophy, Ithaca, New York, Cornell University Press.

CACHIA, P (1973): The Monitor: A Dictionary of Arabic Grammatical Terms, London, Longman.

LEECH, G. N. (1980): A Linguistic Guide to English Poetry, London, Longman.

NASIRU'L-DİN, A. (1968): Daqä' iqu-l cArabiyyati, Beirut, Librairie du Liban.

NICHOLSON, R. N. (1930): A Literary History of the Arabs, Cambridge, C.U.P.

WORMHOUDT, A. (1978): Diwan of Abu-Tayyib Ahmed ibn al-Hussein al-Mutanabbi, vol. vi, William Penn College.

WRIGHT, W. (1979): A Grammar of the Arabic Language, Cambridge, C.U.P. 